FACTA UNIVERSITATIS

Series: Teaching, Learning and Teacher Education Vol. 3, No 2, 2019, pp. 121 - 129

https://doi.org/10.22190/FUTLTE1902121M

Original research paper

\title{
THE INFLUENCE OF THE COORDINATION AND SPEED EXERCISE PROGRAM ON MORPHOLOGICAL CHARACTERISTICS OF CLASS TEACHING PUPILS
}

\author{
UDC 612.766:796.012.1; 572.087-053.5:796.012.1; 371.3::796
}

\author{
Vladimir Momčilović ${ }^{1}$, Zoran Momčilović ${ }^{1}$, Srđan Nikolić \\ ${ }^{1}$ Pedagogical Faculty in Vranje, University of Niš, Serbia \\ ${ }^{2}$ Primary School "Učitelj Tasa”, Niš, Serbia
}

\begin{abstract}
In this paper, the authors presented a study aimed at determining the impact of coordination and speed training programs on morphological characteristics of classroom pupils. The sample of respondents included primary school pupils from Nis, aged 9 and 10 ( \pm 6 months). The sample of 64 respondents was divided into two groups, an experimental and control group, 32 pupils in each group. The respondents of the experimental group were involved in the training process of exercising coordination and speed in additional PE classes, while the control group was involved only in regular PE classes. The results of the multivariate analysis of variance and the univariate analysis of variance showed that there are statistically significant differences in the morphological characteristics of the experimental group of respondents in the final measurement compared to the control group respondents in the skin abdomen (ANTRB), the foreskin of the upper arm (ANNAD), and the skin of the lower leg (ANPTK).
\end{abstract}

Key words: coordination, speed, morphological characteristics, classroom pupils

\section{INTRODUCTION}

Regular teaching of physical education as a complex and delicate social activity aims to provide positive transformation of anthropological characteristics and increase the level of motor skills (abilities) of pupils by using means of physical exercises and specific forms of organization, methods and forms of work. The basic function of physical education is to satisfy the natural biological and psychological needs of children and youth for movement, play and creativity. Accordingly, the basic goal of physical education in its widest form can be defined as the building and perfecting of complex personality by specific means and methods of work (Zdanski and Galić, 2002; Višnjić, 2006).

Received April 24, 2019/Accepted January 15, 2020

Corresponding author: Vladimir Momčilović

Pedagogical Faculty in Vranje, University of Niš, Partizanska 14, 17500 Vranje, Serbia

Phone: +381 17422 962•E-mail: vladmomcilovic@gmail.com 
A large number of scientific researches and direct practice have shown that optimal programming of physical education classes from 7 to 11 years of age can significantly transform morphological and motor skills (abilities) of children, which means that through timely programmed instruction, we can focus, operate in a purposeful and optimal way and change the personality structure into a desired one (Pejčić, Malacko \& Muvrin, 2014)

Anthropological characteristics and abilities of children, especially in the period from 7 to 11 years of age, can be developed most successfully in the so-called. "Sensible phases" when, on the basis of natural laws, the most important pace of individual development is achieved, increase adaptive possibilities in relation to exogenous factors and create particularly favorable conditions for the formation of certain motor skills (abilities) of children (Bala 1981; Malacko 2002; Pržulj 2007).

The development of anthropological characteristics and abilities of children depends primarily on the selection of appropriate program contents, their application and the load, and according to the authors (Gajić et al 1985; Željaskov, 2004; Pržulj, 2006; Milanović, 2007). The correct dosage of loading with children of class teaching enables optimal development of training and achieving expected results at the appropriate age.

Accordingly, the use of physical exercise means should be a properly methodically organized process for the development and maintenance of abilities and traits (motor properties), whereby the contents, methods and workloads of the training should stimulate the dynamic development of children and athletes, following, above all, knowledge on transformational processes for the development of anthropological characteristics.

The aim of this research is to determine the impact of coordination and speed training programs on the morphological characteristics of elementary school students, for the purpose of better planning and programming of regular and additional physical education classes and for providing the most optimal means, methods and workload for the development of morphological characteristics of classroom students

\section{MATERIAL AND METHODS}

\subsection{The subject of the research}

The subject of the research was to investigate the influence of the coordination and speed training programs on the morphological characteristics of the students in the classroom.

\subsection{Sample of respondents}

The sample consisted of 64 elementary school students in Niš, aged 9 and 10 years $( \pm 6$ months). The sample was divided into two groups, experimental and control group, 32 subjects in each group.

\subsection{Sample variables}

We defined the following variables: Medium AOGRK chest volume, AONDL upper arm circumference, AOPTK lower leg circumference, ANTEB abdominal mass, ANTRB abdominal skin set, ANNAD upper arm leather set, ANPTK lower arm. 


\subsection{Experimental treatment}

The control group of subjects was included only in regular physical education classes. 24 teaching hours of 8 weeks were completed. The structure of the curriculum contents of the teaching work was predominantly transformational in character for the development of anthropological features and increasing the level of technical and tactical knowledge of the students. The programming of the work was oriented to determining the content, workload and working methods for the development of morphological characteristics in accordance with the curriculum for primary school. For this purpose, a selection of exercises, dosing and scheduling of training contents were harmonized with the goals and tasks of the program contents of the teaching process.

In the additional physical education classes, an experimental group of subjects implemented a program of co-ordination and speed training as an additional exercise for the development of morphological characteristics over a period of 8 weeks with 24 hours of training (one school class, three times a week ).

The coordination and speed exercise program consisted of coordination and speed exercises. Program of coordination exercises included: limb coordination, catching the bounced ball, jumping over the hurdles with turns, reel forward, reel backward, running the ball, limb coordination. Program of speed exercises included: harmonious arm work, high start exercises, down start, fast steps, high knee lift in gait, foot-to-foot jumps, accelerations.

The measuring instruments used in the study to evaluate the morphological characteristics, circular dimensionality and body mass are: metal measuring tape and scales a subcutaneous adipose tissue: caliper.

The proposed model sample of anthropometric measures for the assessment of morphological characteristics was taken on the basis of the recommendations of the International Biological Program (Lohman, Roche, \& Martorell, 1988).

\subsection{Statistical analysis}

The methods of descriptive statistics and inference statistics were used for data processing, the statistical program for data processing Statistica was used. Descriptive statistics, multivariate analysis of variance, univariate analysis of variance and student t-test were done.

\section{RESULTS}

In this study, the following results were obtained:

Table 1 Basic statistical parameters for estimating the morphological characteristics of the control group at the initial measurement

\begin{tabular}{lccccccc}
\hline An. Measurements & $\mathrm{N}$ & Mean & \multicolumn{1}{c}{ Min. } & Max. & Std. dev. & Skewn. & Kurtos. \\
\hline AOGR & 32 & 68.10 & 62.00 & 76.00 & 14.08 & 0.255 & 0.906 \\
AONDL & 32 & 19.15 & 16.00 & 25.00 & 15.67 & 0.036 & -0.574 \\
AOPTK & 32 & 26.84 & 22.00 & 30.00 & 10.60 & 0.951 & 2.667 \\
ATEŽT & 32 & 40.90 & 31.00 & 47.00 & 52.51 & 0.387 & 1.140 \\
ANTRB & 32 & 13.83 & 7.00 & 18.00 & 52.77 & 0.533 & -0.626 \\
ANNAD & 32 & 17.42 & 13.00 & 20.00 & 7.19 & 0.077 & 0.158 \\
ANPTK & 32 & 15.25 & 10.00 & 17.00 & 4.40 & 0.914 & 0.513 \\
\hline
\end{tabular}


The results shown in Table 1 indicate the test area of anthropometric measures of morphological characteristics on the initial measurement is without statistically significant deviation. The results of tests that evaluate the morphological characteristics of the respondents indicate that the distribution is positive.

Table 2 Basic statistical parameters for the assessment of the morphological characteristics of the control group at the final measurement

\begin{tabular}{lccrcrcr}
\hline An. Measurements & $\mathrm{N}$ & Mean & \multicolumn{1}{c}{ Min. } & Max. & Std.dev. & Skewn. & Kurtos. \\
\hline AOGR & 32 & 68.92 & 63.00 & 78.00 & 4.39 & 0.811 & 0.798 \\
AONDL & 32 & 19.74 & 17.00 & 26.00 & 2.70 & 0.101 & 1.404 \\
AOPTK & 32 & 27.05 & 22.00 & 31.00 & 1.60 & 0.335 & -1.189 \\
ATEŽT & 32 & 41.10 & 33.00 & 50.00 & 6.29 & 0.858 & 1.118 \\
ANTRB & 32 & 13.46 & 7.00 & 17.00 & 55.26 & 0.032 & -0.892 \\
ANNAD & 32 & 16.84 & 12.00 & 19.00 & 8.98 & 0.646 & 0.743 \\
ANPTK & 32 & 14.72 & 9.00 & 17.00 & 3.95 & 0.813 & 0.532 \\
\hline
\end{tabular}

By reviewing the Table 2, in the area of anthropometric measures of morphological characteristics in the final measurement, there is no statistically significant deviation in the control group. The results of tests that evaluate the morphological characteristics of the respondents indicate that the distribution is positive.

Table 3 Basic statistical parameters for the evaluation of the morphological characteristics of the experimental group on the initial measurement

\begin{tabular}{lccrrrrr}
\hline An. Measurements & $\mathrm{N}$ & Mean & \multicolumn{1}{c}{ Min. } & Max. & Std.dev. & Skewn. & Kurtos. \\
\hline AOGR & 32 & 67.40 & 63.00 & 74.00 & 2.25 & 0.541 & 0.111 \\
AONDL & 32 & 18.65 & 15.00 & 23.00 & 4.70 & 0.099 & -0.459 \\
AOPTK & 32 & 27.23 & 23.00 & 31.00 & 2.58 & 0.080 & -0.051 \\
ATEŽT & 32 & 39.74 & 26.00 & 46.00 & 10.23 & 0.769 & 1.214 \\
ANTRB & 32 & 12.56 & 8.00 & 19.00 & 3.14 & -0.110 & -0.814 \\
ANNAD & 32 & 16.83 & 13.00 & 22.00 & 6.89 & 0.801 & 0.355 \\
ANPTK & 32 & 14.72 & 11.00 & 17.00 & 18.45 & -0.712 & -1.290 \\
\hline
\end{tabular}

The results in Table 3 covering the experimental group in the area of anthropometric measures of morphological characteristics on the initial measurement, show no statistically significant deviation. The results of tests that evaluate the morphological characteristics of the respondents indicate that the distribution is positive.

Table 4 Basic statistical parameters for the evaluation of the morphological characteristics of the experimental group at the final measurement

\begin{tabular}{lcrrrrrr}
\hline An. Measurements & $\mathrm{N}$ & \multicolumn{1}{c}{ Mean } & \multicolumn{1}{c}{ Min. } & Max. & Std.dev. & Skewn. & Kurtos. \\
\hline AOGR & 32 & 69.72 & 62.00 & 76.00 & 2.32 & 0.494 & -0.263 \\
AONDL & 32 & 19.38 & 16.00 & 25.00 & 2.12 & 0.781 & 0.168 \\
AOPTK & 32 & 29.43 & 24.00 & 32.00 & 1.70 & 0.291 & 1.135 \\
ATEŽT & 32 & 41.62 & 27.00 & 48.00 & 4.82 & 0.077 & -0.297 \\
ANTRB & 32 & 8.34 & 7.00 & 21.00 & 2.50 & 0.003 & 0.438 \\
ANNAD & 32 & 13.52 & 10.00 & 23.00 & 10.04 & 0.720 & 1.158 \\
ANPTK & 32 & 11.15 & 8.00 & 18.00 & 3.10 & 0.343 & -0.582 \\
\hline
\end{tabular}


The results obtained in Table 4 show no statistically significant deviation in the experimental group in the area of anthropometric measures of morphological characteristics in the final measurement. The results of tests that evaluate the morphological characteristics of the respondents indicate that the distribution is positive.

Tables 5 and 6 show the differences in the results between the experimental and the control group.

Table 5 Multivariate analysis of variance between experimental and control group of subjects in morphological characteristics at initial measurements

\begin{tabular}{cccc}
\cline { 2 - 3 } Legend: Values & $\frac{.725}{233}$ \\
\cline { 2 - 3 } & \multicolumn{2}{c}{ of Bertlet test (Wilks' Lambda), Rao F-approximation (Rao's F) } \\
and level of significance (Q)
\end{tabular}

By analyzing the table 5 in which the results of testing the significance of differences in the level of arithmetic meanings of all anthropometric measures between the initial measurement of the sample of the experimental and control group, no statistically significant difference was determined, since Wilk's Lambda is .725, which by Rao's F-approximation of 1.41 gives significance of differences at the level of $Q=.233$. Therefore, in the applied system of morphological characteristics of the respondents, no statistically significant differences were found.

Table 6 Univariate variance analysis between experimental and control group of subjects in morphological characteristics at initial measurement

\begin{tabular}{lcccc}
\hline Mere & Mean $(\mathrm{E})$ & Mean $(\mathrm{K})$ & F-ratio & $\mathrm{Q}$ \\
\hline AOGR & 67.40 & 68.10 & 1.25 & .157 \\
AONDL & 18.65 & 19.15 & 1.58 & .146 \\
AOPTK & 27.23 & 26.84 & 1.87 & .077 \\
ATEŽT & 39.74 & 40.90 & 1.45 & .358 \\
ANTRB & 12.56 & 13.83 & 1.45 & .125 \\
ANNAD & 16.83 & 17.42 & 1.45 & .224 \\
ANPTK & 14.72 & 15.25 & 1.75 & .127 \\
\hline
\end{tabular}

In Table 6 a univariant analysis of the variance of anthropometric measures of morphological characteristics is presented by comparing the results of the arithmetic mean of the experimental and control group at the initial measurement. Based on the F-ratio coefficients and their significance (Q), it can be concluded that a statistically significant difference was not found for an anthropometric measure between the experimental and the control group.

Then, in Tables 7 and 8 analysis of the difference between the initial and final measurement of the examinees was done by $t$-test

Table 7 contains the results of the $t$-test of the morphological characteristics between the initial and final measurement of the experimental group. After analyzing the results obtained, it is concluded that there is a statistically significant difference in the skin of the abdomen (ANTRB .002), the foreskin skin (ANNAD .000) and the skin of the lower leg (ANPTK $.005)$. 
Table 7 Significance of differences between the arithmetic meanings of the experimental group

\begin{tabular}{lcccc}
\hline Tests & Mean(i) & Mean(f) & T-value & $\mathrm{p}$ \\
\hline AOGR & 67.40 & 69.72 & 1.12 & .347 \\
AONDL & 18.65 & 19.38 & 1.11 & .340 \\
AOPTK & 27.23 & 29.43 & 1.54 & .155 \\
ATEŽT & 39.74 & 41.62 & 1.26 & .149 \\
ANTRB & 12.56 & 8.34 & 3.63 & .002 \\
ANNAD & 16.83 & 13.52 & 4.26 & .000 \\
ANPTK & 14.72 & 11.15 & 3.08 & .005 \\
\hline
\end{tabular}

Table 8 contains the results of the $t$-test of the morphological characteristics between the initial and final measurement of the control group subjects. After analyzing the obtained results, it is concluded that there is no statistically significant difference in morphological characteristics measurements.

Table 8 Significance of differences between the arithmetic mean of the control group subjects

\begin{tabular}{lcccc}
\hline Tests & Mean(i) & Mean(f) & T-value & $\mathrm{p}$ \\
\hline AOGR & 68.10 & 68.92 & 1.46 & .165 \\
AONDL & 19.15 & 19.74 & 1.15 & .368 \\
AOPTK & 26.84 & 27.05 & -0.34 & .748 \\
ATEŽT & 40.90 & 41.10 & -1.66 & .394 \\
ANTRB & 13.83 & 13.46 & -1.35 & .198 \\
ANNAD & 17.42 & 16.84 & -1.26 & .333 \\
ANPTK & 15.25 & 14.72 & -1.51 & .203 \\
\hline
\end{tabular}

Tables 9 and 10 present the differences between the experimental and the control group on the final measurement in the anthropological characteristics.

Table 9 Multivariate analysis of variance of morphological characteristics between the experimental and control group at the final measurement

\begin{tabular}{ccc}
\hline Wilk's Lambda & Rao's F & Q \\
\hline .193 & 12.52 & .000 \\
\hline
\end{tabular}

The results of the multivariate analysis of variance between the experimental and control group on the final measurement indicate that there is a statistically significant intergroup difference in morphological characteristics since Wilk's Lambda equals .193, which by Rao's F-approximation of 12.52 gives the significance of differences at the level of $\mathrm{Q}=.000$. Therefore, in the applied system of morphological characteristics of the subjects, statistically significant differences were found.

In Table 10 a univariant analysis of the variance of measures of morphological characteristics is presented by comparing the results of the arithmetic meanings of the experimental and control group at the final measurement. Based on the F-ratio coefficients and their significance (Q), it can be concluded that a statistically significant difference in the level of morphological characteristics between the experimental and control group in the skin abdomen (ANTRB .000), the upper arm foreskin (ANNAD .000) and skin of the lower leg (ANPTK .000). 
Table 10 Univariant analysis of variance of morphological characteristics between the experimental and control group at the final measurement

\begin{tabular}{lcccc}
\hline Antrop. measurements & Means (E) & Means (K) & F-odnos & Q \\
\hline AOGR & 69.72 & 68.92 & 1.45 & .126 \\
AONDL & 19.38 & 19.74 & 1.47 & .120 \\
AOPTK & 29.43 & 27.05 & 1.55 & .112 \\
ATEŽT & 41.62 & 41.10 & 1.24 & .315 \\
ANTRB & 8.34 & 13.46 & 5.39 & .000 \\
ANNAD & 13.52 & 16.84 & 7.98 & .000 \\
ANPTK & 11.15 & 14.72 & 4.95 & .000 \\
\hline
\end{tabular}

\section{DISCUSSION}

Studies of the effectiveness of specially programmed exercise in additional teaching to develop morphological characteristics in students of classroom teaching indicate that significant transformational effects are achieved (Malacko, 2002; Visnjic, 2006).

Also, many studies indicate that optimal programming of physical education lessons at that age can significantly influence the transformation of anthropological characteristics of children (Gajić et al. 1985; Željaskov, 2004; Pržulj, 2006, 2007; Milanović, 2007; Bala 1981; Malacko 2002; Pejčić, Malacko \& Muvrin, 2014).

Based on the research done so far and the results presented, we can draw the following conclusions:

Multivariate and univariant analysis of the variance between the experimental and control group of the respondents in the morphological characteristics of the initial measurement (Table 5 and Table 6) showed the applied system of morphological characteristics of the respondents were not statistically significantly different.

By analyzing the results of the $t$-test of morphological characteristics between the initial and final measurements of the experimental group (Table 7), we can conclude that there is a statistically significant difference in the skin abdomen (ANTRB .002), the foreskin of the upper arm (ANNAD .000) and the skin of the lower leg (ANPTK .005), while the analysis of the results of the $t$-test of morphological characteristics between the initial and final measurement of the control group subjects (Table 8), we can conclude that there is no statistically significant difference in morphological characteristics.

Multivariate analysis of variance and univariate analysis of the variance of morphological characteristics between the experimental and control group at the final measurement (Table 9 and Table 10) revealed statistically significant differences in the benefit of the experimental group of examinees in the skin abdomen (ANTRB .000), the foreskin of the upper arm (ANNAD .000) and the skin of the lower leg (ANPTK .000).

Based on these conclusions, it can be said that there is a statistically significant influence of the program of exercising coordination and velocity on the variables for assessing the subcutaneous fat tissue (the skin of the abdomen-ANTRB, the foreskin of the upper armANNAD and the skin of the lower leg (ANPTK), while in the variables for estimating the circular dimensionality and body mass (middle circumference of the chest-AOGRK, the circumference of the upper arm-AONDL, the circumference of the lower leg-AOPTK and the body mass-ATEŽT) it does not exist. 


\section{REFERENCES}

Gajić M. i sar. (1985). Osnovi motorike čovjeka. Novi Sad: Fakultet fizičke kulture.

Gužalovskij, A. A. (1984). Probljemi "kritičeskih" periodov ontogenezi i ee značeniji dlja tjeoriji i praktiki fizičeskogo vospitanija [Problems of "critical" period of ontogenesis and their significance for the theory and practice of physical education]. Oĉerki po tjeoriji fiziceskoj kuljturi. Moskva, SSSR: Fizkuljtura i sport.

Kurelić, N., Momirović, K., Stojanović, M., Radojević, Ž. i Viskić-Štalec, N. (1975). Struktura i razvoj morfoloških i motoričkih dimenzija omladine. Beograd: Institut za naučna istraživanja Fakulteta za fizičko vaspitanje Univerziteta u Beogradu.

Lohman, T. G., Roche, A. F., \& Martorell, R. (1988). Antropometric standardization reference manual. Chicago: Human Kinetics Books.

Malacko, J. (2002). Sportski trening. Novi Sad: Fakultet fizičke kulture.

Malacko, J. (2009). Prediktorska valjanost testova eksplozivne i repetitivne snage za dijagnosticiranje aerobne izdržljivosti djevojčica 11-12 godina. U I. Jukić, D Milanović, C. Gregov i S. Šalaj (Ur). 7. godišnja međunarodna konferencija “Kondicijska priprema sportaša 2009” (str 202-205). Zagreb. Kineziološki fakultet Sveučilišta u Zagrebu.

Malacko, J. (2010). Utjecaj genotipa i fenotipa u treningu brzine, agilnosti $i$ eksplozivnosti. 8. godišnja međunarodna konferencija "Kondicijska priprema sportaša 2010." Zagreb. Kineziološki fakultet Sveučilišta u Zagrebu.

Malacko, J., Pejčić, A., \& Tomljenović, B. (2014). The interaction between the morphological characteristics and motor skills of boys and girls aged 7 to 11 . In Milanović, D. and Sporiš, G. (Eds.), 7th International Scientific Conference on Kinesiology (pp. 278-281). Opatija, Croatia.

Lohman, T. G., Roche, A. F., \& Martorell, R. (1988). Antropometric standardization reference manual. Chicago: Human Kinetics Books.

Martin, D. (1992). Grundlagen der Trainingslechre (I und II). Schorndorf: Karl Hofmann.

Mikić, B., Tanović, I., i Bjeković, G. (2010). Kvantitativne promjene motoričkih sposobnosti i nekih morfoloških karakteristika pod uticajem individualnog dopunskog trening u fudbalu. Sport Mont, 2122/VII, 47-53.

Milanović, D. (2007). Teorija treninga, Priručnik za studente sveučilišnog studija. Zagreb: Kineziološki fakultet Sveučilišta u Zagrebu.

Milanović, D. (2007). Teorija treninga, Priručnik za studente sveučilišnog studija. Zagreb: Kineziološki fakultet Sveučilišta u Zagrebu

Milanović, L. (2007). Metodika treninga brzinsko-eksplozivnih svojstava kod djece $i$ mladih, Kondiciona priprema sportaša. Zagreb: Kineziološki fakultet Sveučilišta u Zagrebu.

Pržulj, D. (2006). Osnovi antropomotorike. Pale: Fakultet fizičke kulture.

Pržulj, D. (2007). Efekti kondicione pripreme na razvoj motoričkih sposobnosti mladih sportista u pripremnom periodu. Sport i zdravlje, 2(1), 5-8.

Pržulj, D. (2007). Kondiciona priprema sportista. Pale: Fakultet fizičke kulture.

Pržulj, D. (2008). Efekti bazične pripreme za razvoj funkcionalnih i motoričkih sposobnosti sportista. Sport $i$ zdravlje, 3(1), 5-9.

Pržulj, D., i Cicović, B. (2011). Metrijske karakteristike testova za procjenu fleksibilnosti kod školske djece. Sport i zdravlje, 6(1), 24-26.

Pržulj, D., i Pelemiš M. (2010). Razlike u morfološkim karakteristikama i motoričkim sposobnostima između studenata sportista i nesportista. Sport i zdravlje, 5(2), 31-38.

Višnjić, D. (2006). Nastava fizičkog vaspitanja: od V do VIII razreda osnovne škole: Priručnik za studente, nastavnike i profesore. Beograd: Zavod za udžbenike i nastavna sredstva.

Zaciorski, V. M. (1975). Fizička svojstva sportiste. Beograd: Savez za fizičku kulturu.

Zdanski, I., i Galić, M. (2002). Didaktika fizičkog vaspitanja, Organizacioni oblici nastave u fizičkom vaspitanju (str. 148-165). Banja Luka: Fakultet fizičkog vaspitanja i sporta.

Željaskov, C. (2004). Kondicioni trening vrhunskih sportista. Beograd: Sportska akademija. 


\section{UTICAJ PROGRAMA VEŽBANJA KOORDINACIJE I BRZINE NA MORFOLOŠKE KARAKTERISTIKE UČENIKA RAZREDNE NASTAVE}

U ovom radu autori su predstavili istraživanje koje je imalo za cilj utvrđivanje uticaja programa vežbanja koordinacije i brzine na morfološke karakteristike učenika razredne nastave. Uzorak ispitanika činili su učenici osnovnih škola, uzrasta 9 ilo godina ( \pm 6 meseci) u Nišu. Uzorak od 64 ispitanika podeljen je u dve grupe, eksperimentalnu i kontrolnu grupu, po 32 ispitanika u svakoj grupi. Ispitanici eksperimentalne grupe bili su ukljuceni u trenažni proces vežbanja koordinacije i brzine $u$ dodatnoj nastavi fizičkog vaspitanja dok su ispitanici kontrolne grupe bili ukljuceni samo u redovnu nastavu fizičkog vaspitanja. Rezultati multivarijantne analize varijanse $i$ univarijantne analize varijanse pokazali su da postoje statistički značajne razlike $u$ morfološkim karakteristikama ispitanika eksperimentalne grupe na finalnom merenju u odnosu na ispitanike kontrolne grupe $i$ to $u$ kožnom naboru trbuha (ANTRB), kožnom naboru nadlaktice (ANNAD) i kožnom naboru podkolenice (ANPTK).

Ključne reči: koordinacija, brzina, morfološke karakteristike, učenici razredne nastave. 